\title{
Data report: $X$-ray fluorescence scanning of sediment cores from Holes U1382B, U1383D, U1384A, and 1074A from the North Pond area'
}

\author{
Andreas Türke, ${ }^{2}$ Wolfgang Bach, ${ }^{2}$ and Mian Shahid Mehmood ${ }^{2}$
}

\section{Chapter contents}

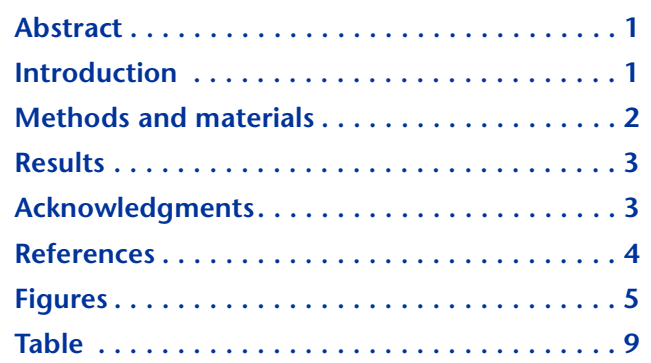

1Türke, A., Bach, W., and Mehmood, M.S., 2014. Data report: X-ray fluorescence scanning of sediment cores from Holes U1382B, U1383D, U1384A, and 1074A from the North Pond area. In Edwards, K.J., Bach, W., Klaus, A., and the Expedition 336 Scientists, Proc. IODP, 336: Tokyo (Integrated Ocean Drilling Program Management International, Inc.).

doi:10.2204/iodp.proc.336.202.2014

${ }^{2}$ Department of Geosciences, Klagenfurter Strasse, 28359 Bremen, Germany. Correspondence author: atuerke@uni-bremen.de

\section{Abstract}

We report semiquantitative geochemical data of four sediment cores from the North Pond area on the western flank of the MidAtlantic Ridge at $22^{\circ} 45^{\prime} \mathrm{N}, 46^{\circ} 06^{\prime} \mathrm{W}$. Three of the sediment cores, from Holes U1382B, U1383D, and U1384A, were drilled during Integrated Ocean Drilling Program Expedition 336. Core from Hole 1074A (Ocean Drilling Program Leg 174B) was also included in this study. The data show highly variable fluorescence intensities for $\mathrm{Ca}, \mathrm{Al}, \mathrm{Si}, \mathrm{Fe}, \mathrm{Mn}$, and $\mathrm{K}$. These variations can be explained by varying proportions and frequencies of foraminiferal sand intercalating with clayey nannofossil ooze. The sand layers show high Ca counts and low counts for all other measured elements. The ooze layers show noticeable counts for $\mathrm{K}, \mathrm{Al}$, and $\mathrm{Si}$, which is interpreted as illite clay fraction. In addition, the concentrations of $\mathrm{Fe}$ and $\mathrm{Mn}$ increase toward the sediment/basement interface in Holes U1382B and Hole 1074A and especially in Hole U1384A, but not in Hole U1383D. The sediment pile at all four drill sites shows slight enrichments in $\mathrm{Fe}$ and $\mathrm{Mn}$ in the uppermost few meters. Rock debris (millimeter to centimeter sized) is present in Holes U1382B and U1383D and to lesser extent in Hole $1074 \mathrm{~A}$, but not in Hole U1384A in the northwesternmost part of the sediment pond. These data provide a cursory assessment of the different sediment lithologies in the North Pond area, in which coupled hydrological-geochemical-microbiological subbasement experiments are currently being conducted.

\section{Introduction}

Oceanic crust cools with increasing distance to the ridge axis, where it is constantly reproduced. Ridge flanks (i.e., the areas between mid-ocean ridges and abyssal plains) are characterized by low-temperature seawater circulation, and it has been estimated that globally $\sim 2 \times 10^{16} \mathrm{~kg}$ of seawater circulates through oceanic crust per year, equivalent to the discharge flux of the global river system (Wheat et al., 2003). Hence, ridge flank systems play an important role in geochemical exchange between crust and seawater.

As the ridge flank crust ages, the seafloor subsides and sediment accumulates. Open circulation of seawater through permeable basement ceases when a continuous sediment layer inhibits access to seawater circulation. However, in areas of rough basement 
topography, such as slow-spread ridge flank crust, ponds of impermeable sediment form in deep areas that are surrounded by exposures of highly permeable basement, though which ventilation of the oceanic crust by circulating seawater is maintained.

North Pond is such a sedimented deep in which sediment thickness reaches $300 \mathrm{~m}$ and is bordered by $>2$ $\mathrm{km}$ high steep slopes of the surrounding rift mountains. Basement drilling and logging revealed that the crust is highly permeable to $\sim 300 \mathrm{~m}$ subbasement and conducive to lateral flow of seawater (Becker et al., 2001). Heat flow measurements indicate that seawater may recharge in the southeastern part of the sediment pond and then flows laterally in a roughly south-to-north direction underneath the impermeable sediment lid (Langseth et al., 1992).

Microbial life in sediment has been assigned an important role as a carbon source in the deep sea. Marine sediment covering ridge flanks in oligotrophic parts of the oceans reveals very low rates of microbial metabolism (D'Hondt et al., 2004). Microbial activity in the North Pond area appears to differ between sandy and clayey lithologies (Picard et al., 2011). Also, it has also been noted that oxygenated seawater circulating within the ocean crust at North Pond constitutes a source of oxygen diffusing upward into the sediment pile (Ziebis et al., 2012; Orcutt et al., 2013). The supply of energy and electron acceptors for the sedimentary biosphere is hence related to both subbasement hydrology and sediment lithology, but the detailed relationships between the nature and physical properties of sediment and rates of microbial metabolism remain poorly constrained.

We present semiquantitative geochemical data obtained by X-ray fluorescence (XRF) scanning for three cores recovered during Integrated Ocean Drilling Program Expedition 336 from Sites U1382, U1383, and U1384 as well as for a core from Ocean Drilling Program Leg 174 Site 1074 (Becker et al., 2001). These data provide a cursory classification of abundance and distribution of different sediment types in the North Pond area. A comprehensive assessment of the distribution of the different sediment types in the North Pond area is required to help put results of microbiological studies into a regional lithologic context.

\section{Methods and materials}

\section{$X$-Ray fluorescence scanning}

Sediment cores were analyzed by XRF scanning. XRF scanning is a semiquantitative method for stepwise geochemical characterization of sediment cores. For detailed description of the method, see Tjallingii et al. (2007). From the chemical data, information about the relative abundances of calcium carbonate and clay can be revealed. The XRF data are merged with visual estimates of foraminiferal sand versus nannofossil ooze.

XRF core scanner data were collected every $1 \mathrm{~cm}$ using generator settings of $10 \mathrm{kV}$, a current of $0.2 \mathrm{~mA}$, and a sampling time of $20 \mathrm{~s}$ directly at the split core surface of the archive half with the XRF core scanner (AVAATECH SERIEL No. 2) at MARUM-University of Bremen (Germany). All XRF data are reported in XRFDATA in "Supplementary material."

The split core surface was covered with a $4 \mu \mathrm{m}$ thin SPEXCerti Prep Ultralene1 foil to avoid contamination of the XRF measurement unit and desiccation of the sediment. The data reported here have been acquired by a Canberra X-PIPS silicon drift detector (SDD; Model SXD 15C-150-500) with $150 \mathrm{eV}$ X-ray resolution, the Canberra digital spectrum analyzer DAS 100, and an Oxford Instruments 50W XTF5011 $\mathrm{X}$-ray tube with rhodium (Rh) target material. Raw data spectra were processed by the analysis of X-ray spectra by the iterative least-squares software (WIN AXIL) package from Canberra Eurisys.

\section{Lithologic units}

Results of shipboard studies during Expedition 336 indicate varied sediment lithologies ranging from nannofossil ooze to foraminiferal sand with occasional layers containing rock debris from the surrounding basement outcrops (see the "Expedition 336 summary" chapter [Expedition 336 Scientists, 2012]). The purpose of this data report is to augment the shipboard core descriptions by systematic core scanning data and observations in order to provide a more comprehensive account of the sediment lithostratigraphy of North Pond. In addition to XRF scanning results, we used natural gamma ray (NGR) and magnetic susceptibility data (see the "Expedition 336 summary" chapter [Expedition 336 Scientists, 2012]) in characterizing the sediment.

We visually identified intervals of foraminiferal sand layers while preparing cores for XRF scanning. Some of these layers were not analyzed by the XRF core scanner, as the poor recovery of the thicker sandy intervals produced a retreated and uneven split core surface, which was unsuitable for X-ray scanning. In the lithologic profiles, visual observations, core scanning data, NGR, and susceptibility were combined to understand the entire sedimentary sequence. Lithostratigraphic units were defined using the following criteria:

- Foraminiferal sand (visual observation);

- Nannofossil ooze (visual observation); 
- Mn nodules (Mn > $4000 \mathrm{cps}$ );

- Illite (K > 8000 cps, $\mathrm{Al}>1000 \mathrm{cps}$, and NGR > $10 \mathrm{cps}) ;$ and

- Magnetite (Fe > 30,000 cps and susceptibility > 100 units).

These units merely account for geochemical enrichments or lithologic properties but do not indicate the actual presence of distinct mineral phases.

\section{Results}

\section{Geochemical data}

\section{Hole U1382B}

Hole $\mathrm{U} 1382 \mathrm{~B}$ is characterized by high $\mathrm{Al}, \mathrm{Si}$, and $\mathrm{K}$ contents both in the uppermost $12 \mathrm{~m}$ and lowermost $5 \mathrm{~m}$ of sediment (Fig. F1). At $\sim 56$ and 62 meters below seafloor (mbsf), two smaller but still significant peaks of these elements were identified. Both Fe and Mn concentrations are highest in the uppermost 12 $\mathrm{m}$ and lowermost $5 \mathrm{~m}$. Foraminiferal sands are most abundant in the uppermost $30 \mathrm{~m}$, with a particularly thick layer between 15 and 25 mbsf. Where XRF scanning was possible, these sandy intervals display very low $\mathrm{Mn}, \mathrm{Fe}, \mathrm{Al}$, and $\mathrm{K}$ concentrations (Fig. F1) and high Ca counts.

\section{Hole U1383D}

Unlike in Hole U1382B, the variability of $\mathrm{Al}, \mathrm{Si}$, and $\mathrm{K}$ in Hole U1383D is much less pronounced, with only slightly increased intensities in the uppermost few meters of the sediment pile. Fe and Mn count rates show a broader range, with increased concentrations near the top of the drilled section. Significant enrichment of these elements toward the sediment/basement interface was not detected in Hole U1383D (Fig. F2). Ca intensities negatively correlate with intensities of all other elements. Despite variable Ca intensities (i.e., calcium carbonate contents), actual layers of foraminiferal sand are rare in Hole U1383D and completely absent below 20 mbsf (Table T1).

\section{Hole U1384A}

Downhole element distribution patterns in Hole U1384A resemble those of Hole U1382B and contrast those of Hole U1383D. Al, Si, and $\mathrm{K}$ are enriched near the top and bottom. The same trend is observed for Fe and Mn (Fig. F3). Ca intensities are negatively correlated with those of all other elements. Eleven intervals of foraminiferal sand are spread across the entire depth of the hole (Table T1).

\section{Hole 1074A}

Downhole element distribution patterns of Hole 1074A resemble those of Holes U1382B and U1384A. Again, $\mathrm{Al}, \mathrm{Si}, \mathrm{K}, \mathrm{Fe}$, and $\mathrm{Mn}$ are enriched near the top and bottom of the sediment pile (Fig. F4). The distribution of foraminiferal sand in Hole 1074A differs from that in the other three holes (Table T1). There are numerous (29) and mostly very thin $(1-5 \mathrm{~cm})$ layers in the uppermost $56 \mathrm{~m}$ of the drilled sequence but no sand at all between 56 mbsf and the bottom of the hole.

\section{Lithostratigraphy}

The results of core logging and X-ray scanning were used to construct lithologic charts employing the criteria given in "Methods and materials" (Figs. F1, F2, F3, F4). These charts illustrate the lithologic sequence and highlight the variations in the lithostratigraphy between different sites in the North Pond area. Lithologies of Holes U1382B, U1384A, and $1074 \mathrm{~A}$ resemble each other, with illite and $\mathrm{Mn}$ nodules (and occasionally magnetite) occurring at the top and bottom of each respective core. However, core from Hole U1383D does not show any of these features near the sediment/basement interface. Furthermore, a significant magnetite layer (likely represented by ultramafic basement rocks) was identified in Hole U1382B at $~ 49-54$ mbsf. In general, rock debris is most abundant at Site U1382, intermediate at Sites U1383 and 1074, and absent at Site U1384. The occurrence of foraminiferal sand layers is highly variable with respect to both vertical distribution within individual holes and lateral distribution between the different sites. Sand appears to be scarce in the lowermost sections of all cores, where clay contents seem to be greatest.

The particularly strong enrichments of Fe and $\mathrm{Mn}$ in the bottom sections of Holes 1074A and U1384A are noteworthy. Detailed geochemical studies are required to test if these enrichments are related to upwelling of basement fluids in the northwestern part of North Pond.

\section{Acknowledgments}

This research used data acquired at the XRF Core Scanner Laboratory at the MARUM-Center for Marine Environmental Sciences, University of Bremen, Germany. We thank Ulla Röhl, Thomas Westerhold, and Vera Luckies for help with the analyses. This research used samples and data provided by Integrated Ocean Drilling Program (IODP). Funding was provided by the German Research Foundation (DFG) 
with Grant BA1605-10. We also thank the anonymous reviewer for his or her helpful suggestions.

\section{References}

Becker, K., Bartetzko, A., and Davis, E.E., 2001. Leg 174B synopsis: revisiting Hole 395A for logging and long-term monitoring of off-axis hydrothermal processes in young oceanic crust. In Becker, K., and Malone, M.J. (Eds.), Proc. ODP, Sci. Results, 174B: College Station, TX (Ocean Drilling Program), 1-12. doi:10.2973/ odp.proc.sr.174B.130.2001

D’Hondt, S., Jørgensen, B.B., Miller, D.J., Batzke, A., Blake, R., Cragg, B.A., Cypionka, H., Dickens, G.R., Ferdelman, T., Hinrichs, K.-U., Holm, N.G., Mitterer, R., Spivack, A., Wang, G., Bekins, B., Engelen, B., Ford, K., Gettemy, G., Rutherford, S.D., Sass, H., Skilbeck, C.G., Aiello, I.W., Guerin, G., House, C.H., Inagaki, F., Meister, P., Naehr, T., Niitsuma, S., Parkes, R.J., Schippers, A., Smith, D.C., Teske, A., Wiegel, J., Naranjo Padillo, C., and Solis Acosta, J.L., 2004. Distributions of microbial activities in deep subseafloor sediments. Science, 306(5705):22162221. doi:10.1126/science.1101155

Expedition 336 Scientists, 2012. Expedition 336 summary. In Edwards, K.J., Bach, W., Klaus, A., and the Expedition 336 Scientists, Proc. IODP, 336: Tokyo (Integrated Ocean Drilling Program Management International, Inc.). doi:10.2204/iodp.proc.336.101.2012

Langseth, M.G., Becker, K., Von Herzen, R.P., and Schultheiss, P., 1992. Heat and fluid flux through the sediment on the western flank of the Mid-Atlantic Ridge: a hydro- geological study of North Pond. Geophys. Res. Lett., 19(5):517-520. doi:10.1029/92GL00079

Orcutt, B.N., Wheat, C.G., Rouxel, O., Hulme, S., Edwards, K.J., and Bach, W., 2013. Oxygen consumption rates in subseafloor basaltic crust derived from a reaction transport model. Nat. Commun., 4:2539. doi:10.1038/ncomms3539

Picard, A., and Ferdelman, T.G., 2011. Linking microbial heterotrophic activity and sediment lithology in oxic, oligotrophic sub-seafloor sediments of the North Atlan-tic Ocean. Front. Microbiol., 2:263. doi:10.3389/ fmicb.2011.00263

Tjallingii, R., Röhl, U., Kölling, M., and Bickert, T., 2007. Influence of the water content on X-ray fluorescence core-scanning measurements in soft marine sediments. Geochem., Geophys., Geosyst., 8(2):Q02004. doi:10.1029/ 2006GC001393

Wheat, C.G., McManus, J., Mottl, M.J., and Giambalvo, E., 2003. Oceanic phosphorus imbalance: magnitude of the mid-ocean ridge flank hydrothermal sink. Geophys. Res. Lett., 30(17):1895-1898. doi:10.1029/2003GL017318

Ziebis, W., McManus, J., Ferdelman, T., Schmidt-Schierhorn, F., Bach, W., Muratli, J., Edwards, K.J., and Villinger, H., 2012. Interstitial fluid chemistry of sediments underlying the North Atlantic Gyre and the influence of subsurface fluid flow. Earth Planet. Sci. Lett., 323324:79-91. doi:10.1016/j.epsl.2012.01.018

Initial receipt: 8 October 2013

Acceptance: 1 April 2014

Publication: 21 May 2014

MS 336-202 
Figure F1. X-ray fluorescence scanner intensities for $\mathrm{Mn}, \mathrm{Fe}, \mathrm{Al}, \mathrm{K}, \mathrm{Si}$, and $\mathrm{Ca}$, Hole U1382B. The lithology column was created based on geochemical and supplementary susceptibility and natural gamma ray data. Dashed lines indicate criteria used for lithostratigraphic units. Alternative versions of this figure with $\mathrm{Ca} /$ totals and $\log (\mathrm{Ca} / \mathrm{Al})$ can be found in XRFDATA in "Supplementary material."
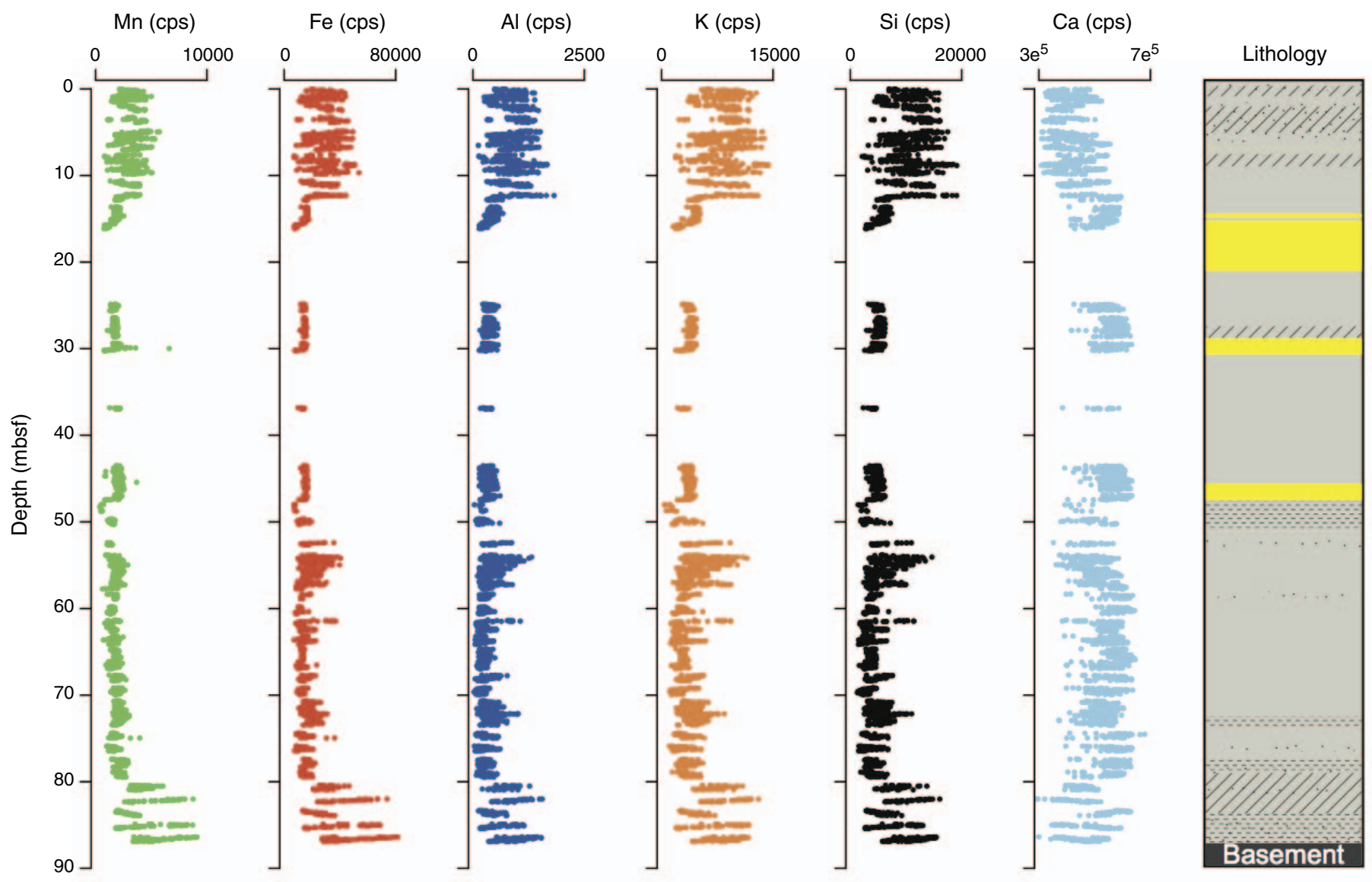

\begin{tabular}{|l|l|}
\hline & Foraminiferal sand \\
& Nannofossil ooze \\
$Y / / / /$ & Mn nodules \\
& Magnetite \\
$\quad$ Illite \\
\hline
\end{tabular}


Figure F2. X-ray fluorescence scanner intensities for $\mathrm{Mn}, \mathrm{Fe}, \mathrm{Al}, \mathrm{K}, \mathrm{Si}$, and $\mathrm{Ca}$, Hole U1383D. The lithology column was created based on geochemical and supplementary susceptibility and natural gamma ray data. Dashed lines indicate criteria used for lithostratigraphic units. Alternative versions of this figure with $\mathrm{Ca} /$ totals and $\log (\mathrm{Ca} / \mathrm{Al})$ can be found in XRFDATA in "Supplementary material."
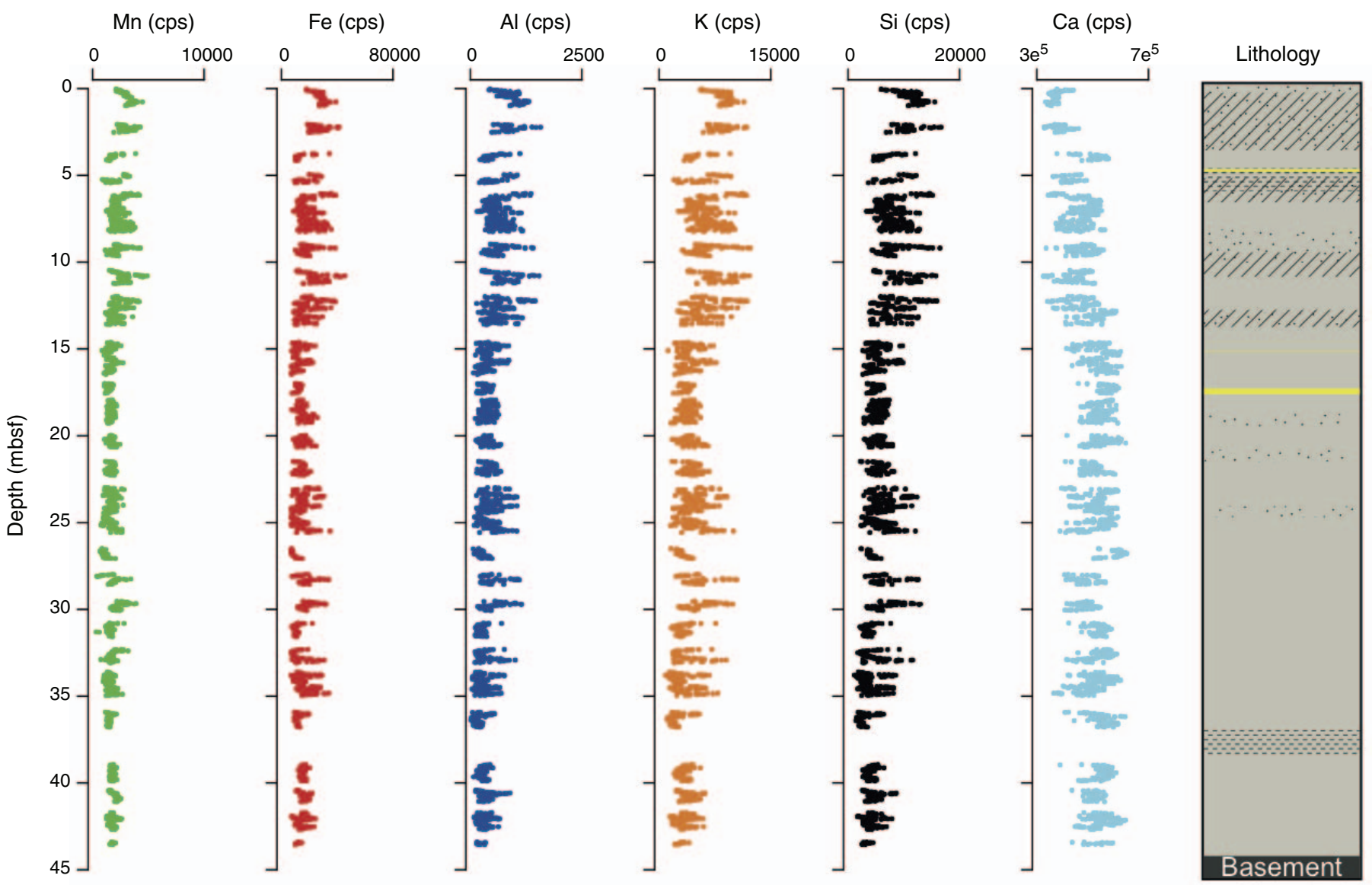

\begin{tabular}{|ll|}
\hline & Foraminiferal sand \\
& Nannofossil ooze \\
U////, Mn nodules & Magnetite \\
\hdashline$\quad$ Illite \\
\hline
\end{tabular}


Figure F3. X-ray fluorescence scanner intensities for $\mathrm{Mn}, \mathrm{Fe}, \mathrm{Al}, \mathrm{K}, \mathrm{Si}$, and $\mathrm{Ca}$, Hole U1384A. The lithology column was created based on geochemical and supplementary susceptibility and natural gamma ray data. Dashed lines indicate criteria used for lithostratigraphic units. Alternative versions of this figure with $\mathrm{Ca} /$ totals and $\log (\mathrm{Ca} / \mathrm{Al})$ can be found in XRFDATA in "Supplementary material."
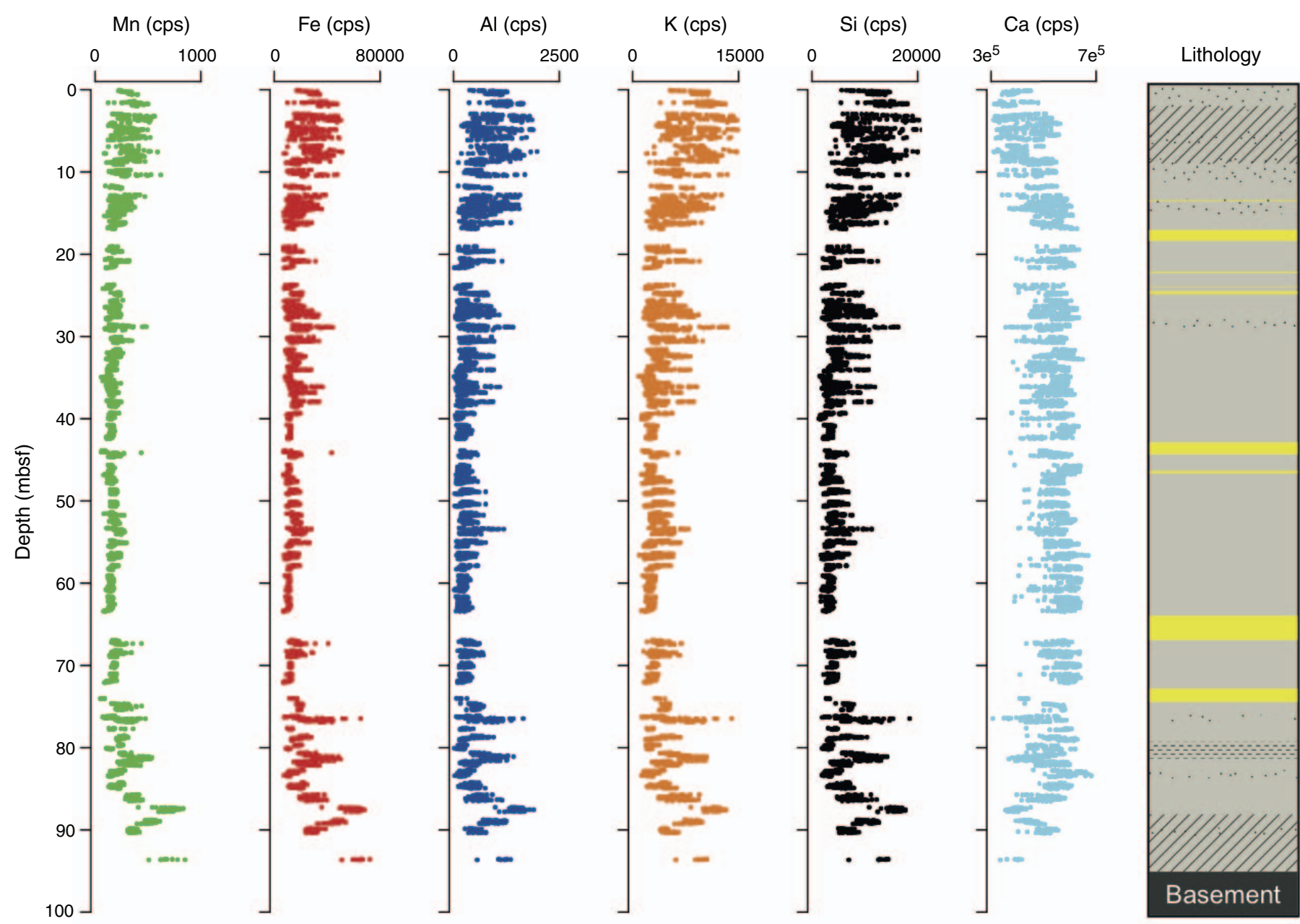

\begin{tabular}{|ll|}
\hline & Foraminiferal sand \\
& Nannofossil ooze \\
$V / / / /$ & Mn nodules \\
& Magnetite \\
\hdashline$\quad$ Illite \\
\hline
\end{tabular}


Figure F4. X-ray fluorescence scanner intensities for $\mathrm{Mn}, \mathrm{Fe}, \mathrm{Al}, \mathrm{K}, \mathrm{Si}$, and $\mathrm{Ca}$, Hole 1074A. The lithology column was created based on geochemical and supplementary susceptibility and natural gamma ray data. Dashed lines indicate criteria used for lithostratigraphic units. Alternative versions of this figure with $\mathrm{Ca} /$ totals and $\log (\mathrm{Ca} / \mathrm{Al})$ can be found in XRFDATA in "Supplementary material."
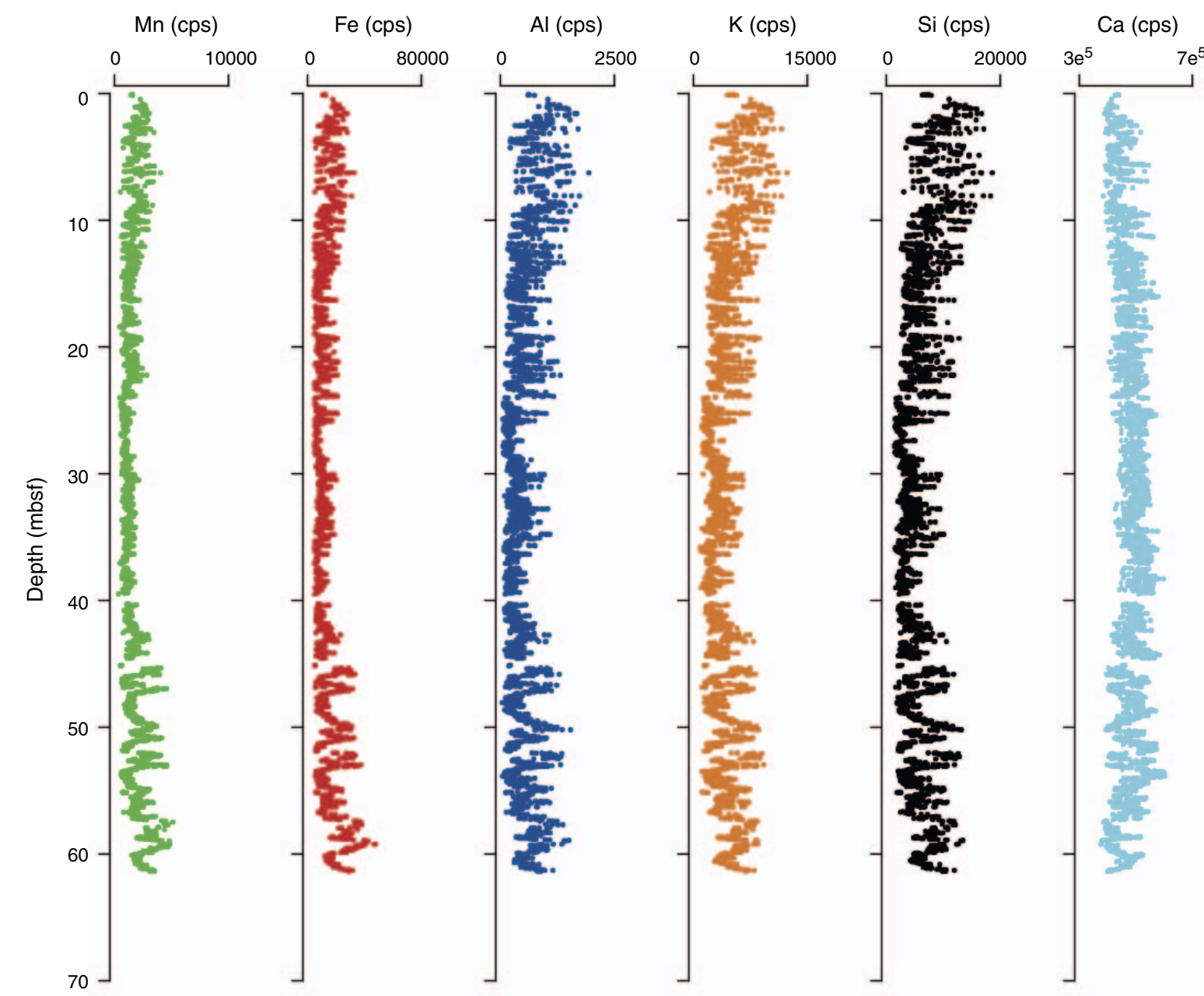

Lithology

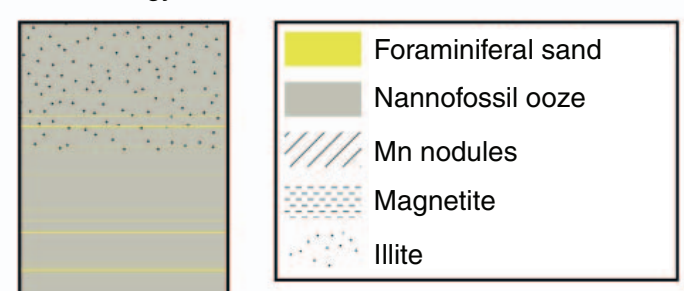


Table T1. Subseafloor depths of foraminiferal sand intervals, Holes U1382B, U1383D, U1384A, and 1074A. (Continued on next page.)

\begin{tabular}{|c|c|c|c|}
\hline \multicolumn{4}{|c|}{ U1382B } \\
\hline Core & Section & Interval (mbsf) & Foraminiferal Sand layer (mbsf) \\
\hline \multirow{2}{*}{$2 \mathrm{H}$} & \multirow{2}{*}{3} & \multirow{2}{*}{$7.57-9.07$} & $7.80-8.06$ \\
\hline & & & $8.38-8.44$ \\
\hline $3 \mathrm{H}$ & 1 & $15.00-16.50$ & $15.68-16.20$ \\
\hline $3 \mathrm{H}$ & 2 & $16.50-18.00$ & \multirow{4}{*}{$16.50-22.50$} \\
\hline $3 \mathrm{H}$ & 3 & $18.00-19.50$ & \\
\hline $3 \mathrm{H}$ & 4 & $19.50-21.00$ & \\
\hline $3 \mathrm{H}$ & 5 & $21.00-22.50$ & \\
\hline $4 \mathrm{H}$ & 5 & $29.35-30.85$ & \multirow{2}{*}{$30.25-32.25$} \\
\hline $4 \mathrm{H}$ & 6 & $30.85-32-25$ & \\
\hline $6 \mathrm{H}$ & 5 & $47.48-47.98$ & \multirow{2}{*}{$47.48-49.48$} \\
\hline $6 \mathrm{H}$ & 6 & $47.89-49.48$ & \\
\hline
\end{tabular}

\begin{tabular}{|c|c|c|c|}
\hline \multicolumn{4}{|c|}{ U1383D } \\
\hline Core & Section & Interval (mbsf) & Foraminiferal Sand layer (mbsf) \\
\hline $2 \mathrm{H}$ & 1 & $5.10-5.95$ & $5.10-5.26$ \\
\hline $3 \mathrm{H}$ & 1 & \multirow{2}{*}{$14.60-15.47$} & $14.94-14.95$ \\
$3 \mathrm{H}$ & 1 & & $15.10-15.14$ \\
\hline $3 \mathrm{H}$ & 3 & $16.97-18.47$ & $17.59-17.92$ \\
\hline
\end{tabular}

\begin{tabular}{|c|c|c|c|}
\hline \multicolumn{3}{|c|}{ U1384A } \\
\hline Core & Section & Interval (mbsf) & Foraminiferal Sand layer (mbsf) \\
\hline $2 \mathrm{H}$ & 7 & $12.74-14.24$ & $13.24-13.28$ \\
\hline $3 \mathrm{H}$ & 4 & $17.48-18.98$ & $17.48-18.98$ \\
\hline $3 \mathrm{CC}$ & & $21.98-22.16$ & $21.98-22.16$ \\
\hline $4 \mathrm{H}$ & & & $23.60-23.68$ \\
\hline $4 \mathrm{H}$ & \multirow{2}{*}{1} & $23.60-23.99$ & $23.77-23.83$ \\
\cline { 1 - 1 } & & & $23.88-23.93$ \\
\hline $4 \mathrm{H}$ & 2 & $23.99-25.49$ & $24.21-24.65$ \\
\hline $6 \mathrm{H}$ & 1 & $42.60-44.10$ & $42.60-44.10$ \\
\hline $6 \mathrm{H}$ & 3 & $45.60-47.10$ & $46.26-46.40$ \\
\hline $8 \mathrm{H}$ & 3 & $63.67-65.17$ & \multirow{2}{*}{$63.67-66.67$} \\
\hline $8 \mathrm{H}$ & 4 & $65.17-66.67$ & \\
\hline $9 \mathrm{H}$ & 2 & $71.61-73.11$ & \multirow{2}{*}{$72.33-73.99$} \\
\hline $9 \mathrm{H}$ & 3 & $73.11-74.61$ & \\
\hline
\end{tabular}

\begin{tabular}{|c|c|c|c|}
\hline \multicolumn{5}{|c|}{$1074 \mathrm{~A}$} \\
\hline Core & Section & Interval (mbsf) & Foraminiferal Sand layer (mbsf) \\
\hline $1 \mathrm{H}$ & 1 & $0.00-1.50$ & $0.71-0.72$ \\
\hline $1 \mathrm{H}$ & 3 & $3.00-4.50$ & $4.29-4.31$ \\
\hline \multirow{2}{*}{$1 \mathrm{H}$} & 5 & $5.51-6.24$ & $5.55-5.59$ \\
\cline { 4 - 4 } & & & $6.15-6.24$ \\
\hline \multirow{2}{*}{$2 \mathrm{H}$} & \multirow{2}{*}{1} & $6.50-8.00$ & $6.91-6.94$ \\
\cline { 4 - 4 } & & & $7.42-7.49$ \\
\cline { 4 - 4 } & & &
\end{tabular}


Table T1 (continued).

\begin{tabular}{|c|c|c|c|}
\hline $2 \mathrm{H}$ & 2 & $8.00-9.50$ & $9.39-9.43$ \\
\hline \multirow{3}{*}{$2 \mathrm{H}$} & \multirow{3}{*}{4} & \multirow{3}{*}{$11.00-12.50$} & $11.41-11.43$ \\
\hline & & & $11.85-11.87$ \\
\hline & & & $12.20-12.23$ \\
\hline $2 \mathrm{H}$ & 5 & $12.50-14.00$ & $12.98-13.03$ \\
\hline \multirow{3}{*}{$2 \mathrm{H}$} & \multirow{3}{*}{6} & \multirow{3}{*}{$14.00-15.50$} & $14.81-14.85$ \\
\hline & & & $15.11-15.13$ \\
\hline & & & $15.41-15.47$ \\
\hline $3 \mathrm{H}$ & 2 & $17.50-19.00$ & $17.98-18.00$ \\
\hline $3 \mathrm{H}$ & 3 & $19.00-20.50$ & $20.37-20.41$ \\
\hline $3 \mathrm{H}$ & 6 & $23.50-25.00$ & $24.27-24.29$ \\
\hline $4 \mathrm{H}$ & 2 & $27.00-28.50$ & $27.05-27.37$ \\
\hline $4 \mathrm{H}$ & 4 & $30.00-31.50$ & $30.04-30.07$ \\
\hline $4 \mathrm{H}$ & 7 & $34.50-34.95$ & $34.61-34.66$ \\
\hline $5 \mathrm{H}$ & 2 & $36.50-38.00$ & $37.11-37.39$ \\
\hline $5 \mathrm{H}$ & 3 & $38.00-39.50$ & \multirow{2}{*}{$39.45-40.27$} \\
\hline $5 \mathrm{H}$ & 4 & $39.50-41.00$ & \\
\hline $5 \mathrm{H}$ & 6 & $41.00-42.50$ & $42.51-42.59$ \\
\hline $6 \mathrm{H}$ & 1 & $44.50-46.00$ & $44.89-45.40$ \\
\hline \multirow{2}{*}{$6 \mathrm{H}$} & \multirow{2}{*}{2} & \multirow{2}{*}{$46.00-47.50$} & $46.50-46.51$ \\
\hline & & & $46.81-46.90$ \\
\hline $6 \mathrm{H}$ & 3 & $47.50-49.00$ & $48.21-48.22$ \\
\hline $7 \mathrm{H}$ & 1 & $54.00-55.50$ & $55.15-55.29$ \\
\hline
\end{tabular}

